Tersedia Online di http://journal.unismuh.ac.id/index.php/otoritas

Otoritas : Jurnal Ilmu Pemerintahan, 6 (2), Oktober 2016, 112-119

\title{
Analisis Implementasi Kebijakan Pos Pemberdayaan Keluarga (Posdaya) di Kota Malang
}

\author{
Restu Karlina*)1, Isma Adila1, Ayu Kusumastuti1 \\ ${ }^{1}$ Fakultas Ilmu Sosial dan Ilmu Politik, Universitas Brawijaya, Jalan. Veteran, Ketawanggede, Kec. \\ Lowokwaru, Kota Malang, Jawa Timur , Indonesia
}

Diterima : 5 Agustus 2016; Disetujui : 25 September 2016; Dipublikasikan 14 Oktober 2016

\begin{abstract}
Family empowerment program was initiated by Professor Haryono Suyono head of the National Population and Family Planning during the Soeharto era. Malang included in Posdaya II East Java region which is coordinated by the University of Merdeka. Formally Posdaya in Malang commenced in 2014, with the memorandumm of understanding between coordinator Posdaya and the Mayor of Malang. The MoU content provides agremeent for divisions devided the area assisted by the college. One of the Posdaya in Malang that goes well is Posdaya in Subdistrict Penanggungan particularly in RT 04 RW 06. There are three forms of Posdaya in this village namely Posdaya Sunday market, Posdaya pottery and Posdaya greening. The results showed Posdaya in RT 04 RW 06 goes well because of some factors such as the synergy between communities with college companion. College companion managed to provide accompaniment programs based on community needs.
\end{abstract}

Keywords: posdaya; implementation; community; Penanggungan urban communities

\begin{abstract}
Abstrak
Program pos pemberdayaan keluarga awal mulanya diinisiasi oleh Profesor Haryono Suyono kepala Badan Kependudukan dan Keluarga Berencana Nasional pada masa pemerintahan Soeharto. Malang termasuk dalam posdaya wilayah II Jawa Timur yang dikoordinasi oleh Universitas Merdeka. Secara legal formal posdaya di Malang mulai dilaksanakan tahun 2014, dengan ditandatanganinya MoU antara koordinator Posdaya dengan Walikota Malang. Mou tersebut berisi kesepakatan untuk pembagian daerah dampingan oleh perguruan tinggi. Di Malang salah satu posdaya yang berjalan dengan baik adalah Posdaya di Kelurahan Penanggungan khususnya di RT 04 RW 06. Ada tiga bentuk posdaya di Kelurahan ini yaitu posdaya pasar minggu, posdaya gerabah dan posdaya penghijauan. Hasil penelitian menunjukan posdaya di RT 04 RW 06 dapat dikatakan berjalan baik karena beberapa hal yaitu adanya sinergitas antara masyarakat dengan perguruan tinggi pendamping. Perguruan tinggi pendamping berhasil memberikan program pendampingan sesuai kebutuhan masyarakat.
\end{abstract}

Kata kunci : posdaya; implementasi; masyarakat; Kelurahan Penanggungan

Cara Penulisan Sitasi : Karlina, R., Adila, I., Kusumastuti, A. (2016). Analisis Implementasi Kebijakan Pos Pemberdayaan Keluarga (Posdaya) di Kota Malang. Otoritas : Jurnal Ilmu Pemerintahan, 6(2), 112-119.

*)Penulis Korespondensi.

E-Mail : restu.karlina@ub.ac.id

Copyright (C) 2016, Otoritas : Jurnal Ilmu Pemerintahan, p-ISSN: 2088-3706, e-ISSN: 2502-9320 
Tersedia Online di http://journal.unismuh.ac.id/index.php/otoritas

Otoritas : Jurnal Ilmu Pemerintahan, 6 (2), Oktober 2016, 113

\section{Pendahuluan}

Program posdaya yang sedang diterapkan di Kota Malang tidak terlepas dari Instruksi Presiden Nomor 6 Tahun 2007 tentang Kebijakan Percepatan Pengembangan Sektor Riil dan Pemberdayaan Usaha Mikro, Kecil, dan Menengah (UMKM). Berdasarkan instruksi tersebut, Walikota Malang dengan tugas, fungsi, kewenangan, dan semangat peduli wong cilik nya, mengambil langkah -langkah untuk meningkatkan pertumbuhan ekonomi kerakyatan. Dengan ekonomi kerakyatan, diharapkan dapat mengurangi angka kemiskinan di Kota Malang setidaknya hingga 5\% dari keseluruhan yang ada. Kemiskinan menjadi isu strategis yang sedang dihadapi Kota Malang. Angka kemiskinan yang masih tinggi menjadi salah satu problem tersendiri, apalagi dengan adanya semangat peduli wong cilik, arah pembangunan Kota Malang sengaja diarahkan agar dapat dinikmati masyarakat miskin.

Posdaya merupakan wadah yang didalamnya terdiri dari kelompok maupun perorangan dengan mengutamakan 8 fungsi keluarga, yaitu fungsi agama, fungsi cinta kasih, fungsi perlindungan, fungsi reproduksi dan kesehatan, fungsi pendidikan, fungsi sosial budaya, fungsi ekonomi, dan fungsi lingkungan. Program ini merupakan program pemberdayaan pada seluruh anggota keluarga, yang pada akhirnya merangsang sikap kebersamaan di dalam keluarga.

Posdaya menjalankan fungsi pemberdayaan masyarakat, dimana Pemberdayaan adalah proses mengembangkan, memandirikan, menswadayakan, memperkuat posisi tawar menawar masyarakat lapisan bawah terhadap kekuatan-kekuatan penekan di segala bidang dan sektor kehidupan (Eko, 2002).

Adapun beberapa tahap-tahap yang bisa dilalui dalam melaksanakan pemberdayaan masyarakat, yaitu pertama adalah adanya tahap penyadaran dan pembentukan perilaku menuju sadar dan peduli sehingga merasa membutuhkan peningkatan diri. Kedua adalah tahap transformasi dimana kemampuan berupa wawasan pengetahuan, kecakapan dan keterampilan agar terbuka juga pikiranpikiran dari masyarakat sehingga dapat di jadikan sebuah landasan dalam pembangunan. Ketiga adalah tahap peningkatan intelektual, sehingga masyarakat yang akan diberdayakan nantinya akan mengalami pengalaman-pengalaman yang baru dan nantinya membuat masyarakat lebih berkembang (Teguh, 2004).

Dalam program posdaya yang memuat pemberdayaan fungsi ekonomi atau kewirausahaan, sasaran utamanya adalah anggota keluarga (ayah,ibu,anak). Jenis kegiatannya antara lain : (1) mendorong agar keluarga-keluarga yang belum berusaha dan tidak bekerja, untuk mulai bergabung dengan kelompokkelompok usaha mikro yang telah ada di sekitar kediamannya. (2) memfasilitasi terlaksananya berbagai pelatihan kewirausahaan serta dukungan pendampingan, baik bagi mereka yang baru memulai usaha, maupun bagi mereka yang telah memiliki usaha namun membutuhkan peningkatan pengetahuan dan keterampilan usaha. (3) mengusahakan kerjasama dengan bank atau lembaga keuangan, dengan tujuan agar keluarga mendapat kesempatan bantuan pendanaan. (4) mengusahakan kerjasama dengan para pengusaha untuk membentuk koperasi sehingga dapat menolong keluarga lain yang relatif kurang mampu untuk bergabung menjadi anggota dan ikut aktif secara gotong-royong. (5) mengadakan kerjasama dengan keluarga atau pengusaha di daerah lain yang bisa memperluas pemasaran produk yang dihasilkan oleh anggota posdaya ke daerah yang lebih luas. (6) membantu atau mendampingi anggota posdaya mendirikan pusat-pusat perdagangan, warung, tempat usaha, dengan cara membantu permodalan atau 
Tersedia Online di http://journal.unismuh.ac.id/index.php/otoritas

Otoritas : Jurnal Ilmu Pemerintahan, 6 (2), Oktober 2016, 114

membantu agunan pinjaman ke bank atau lembaga keuangan yang ada.

Pelaksanaan program posdaya di Kota Malang termasuk dalam koordinator posdaya wilayah Jawa Timur II. Dalam pelaksanaannya, pemerintah Kota Malang bekerjasama dengan unsur perbankan, unsur perguruan tinggi, unsur SKPD (Satuan Kerja Perangkat Daerah), unsur kecamatan se-kota malang, dan asisten administrasi pembangunan. Dari pertemuan pertama dicapai kesepakatan penandatanganan nota kesepahaman (MoU) dan kerjasama dalam pengentasan kemiskinan dan peningkatan sumber daya manusia sesuai tugas dan fungsi masing-masing. Pemerintah memiliki peran sebagai fasilitator yang mampu memadukan antara program posdaya dengan program kerja SKPD yang sesuai. Pihak universitas mengkaji potensi dan kebutuhan yang ada di masyarakat dan juga meminta ijin kelurahan yang bersangkutan. Kelurahan menjadi penghubung antara pihak universitas dengan masyarakat. Kemudian langkah sosialisasi dan pengenalan program posdaya dilakukan, sekaligus menawarkan pembinaan pada masyarakat.

Dalam Posdaya, diharapkan dapat tercipta sebuah sistem tata kelola pemerintahan yang baik (Good Governance). Tata pemerintahan adalah sebuah mekanime interaksi antara pemerintah, sektor swasta dan masyarakat untuk memformulasikan sebah kesepakatan kebijakan pembangunan pada sebuah wilayah hukum dan administratif tertentu.

Dengan tata kelola ini, diharapkan pembangunan akan lebih transparan, memiliki proses partisipasi masyarakat serta akuntabel. Sesuai dengan 8 karakteristik utama Good Governance, dimana tata kelola pemerintah yang baik dapat menciptakan partisipatif masyarakat, konsensus, akuntabel, transparan, responsif, efektif dan efisien, inklusif dan merata (Sheng, n.d).

Ada beberapa penelitian mengenai
Posdaya di Indonesia, seperti penelitian yang dilakukan oleh Anwas (2012) terkait dengan efektifitas Model PAUD Posdaya sebagai alternatif pelaksanaan pendidikan anak usia dini. Selain itu adapula penelitian Naufal dan Kusumastuti (2016) yang menitikberatkan pada evaluasi Program Posdaya selama pendiriannya di Kabupaten Bogor. Atau pada penelitian Asripah (2014) yang membahas mengenai peranan Posdaya dalam meningkatkan kesejahteraan masyarakat.

Dalam penelitian ini, implementasi program posdaya akan dilihat pada lokasi Kelurahan Penanggungan RT.04/RW.06 Kecamatan Klojen Kota Malang. Posdaya yang ada di RT 04 ini ada tiga jenis yaitu posdaya pasar minggu dimana program tersebut di khususkan untuk ibu-ibu, posdaya kerajinan gerabah dimana program tersebut di peruntukkan untuk Bapak-Bapak, dan yang ketiga adalah posdaya penghijauan yang di peruntukkan kelompok pemuda. Alasan dipilih lokasi tersebut sebagai lokasi penelitian dikarenakan pada site ini terdapat prosesproses kerjasama antara stakeholder perangkat desa, masyarakat, sektor swasta dan universitas secara intensif meskipun implementasi program ini masih terkesan baru.

\section{Metode Penelitian}

Desain penelitian menggunakan metode penelitian kualitatif dengan pendekatan deskriptif. Penggunaan metode kualitatif dengan alasan untuk mempermudah penyesuaian prinsipprinsip umum dalam mengumpulkan dan memperoleh pemahaman responden. Metode deskriptif memberikan gambaran atas obyek, kasus, dan situasi-situasi dengan teliti. Metode ini merangkai kenyataan menjadi suatu cerita yakni menguraikan secara teratur suatu masalah, keadaan, peristiwa secara nyata, untuk itu, untuk menyempurnakan metode ini tidak dapat berhenti pada pengumpulan data semata, tetapi harus dilanjutkan 
Tersedia Online di http://journal.unismuh.ac.id/index.php/otoritas

Otoritas : Jurnal Ilmu Pemerintahan, 6 (2), Oktober 2016, 115

dengan analisis dan interpretasi terhadap data sehingga dapat menelaah dan menganalisis data dalam rangkaian yang sempurna.

Sumber data dalam penelitian ini ada dua yaitu data primer, data primer dalam penelitian ini bersumber dari observasi yang tidak terstruktur dan wawancara. Lokus dari penelitian ini adalah Masyarakat Kelurahan Penanggungan yang terdiri dari $8 \mathrm{RW}$ dan 45 RT tentunya program posdaya ini belum semua RT melaksanakan posdaya.

Sumber daya berikutnya adalah data sekunder, data yang digunakan yaitu, Surat Perjanjian Kerjasama (SPK) Program Pengembangan Posdaya di Wilayah Malang Raya, jadwal pelatihan posdaya yang disusun oleh STIKMA Internasional, dokumen LPPM Posdaya dari Universitas Tribhuwana Tunggadewi Malang, MoU antara Walikota Malang dan Rektor Universitas Merdeka terkait Posdaya, contoh proposal posdaya dari Kelurahan Penanggungan, data wilayah posdaya binaan perguruan tinggi wilayah Jawa Timur II, data perkembangan kredit posdaya Kota Malang, presentasi posdaya Universitas Merdeka, dan undangan KKN tematik LPPM Universitas Brawijaya.

Informan dalam penelitian ini adalah tokoh yang berasal dari masyarakat atau pelaku langsung dari kegiatan pemberdayaan POSDAYA yang ada di RT 04/RW 06. Informan adalah tokoh penggerak dalam kegiatan tersebut dan memiliki peran penting dalam berjalannya pemberdayaan.

Sesuai dengan kategori tersebut maka terdapat beberapa informan yang kami wawancarai, yaitu Dhoni Rathomi, sebagai Kasubag Pembinaan BUMD Bagian Perekonomian Sekretaris Daerah Kota Malang, Andayun Sri Afiana sebagai Kepala Bidang Kesejahteraan Dan Pemberdayaan Masyarakat Kota Malang Badan Keluarga Berencana dan Pemberdayaan Masyarakat, Dwi Hermawan Purnomo sebagai Lurah Kelurahan
Penanggungan, Nesyi Prima Dewi sebagai Seksi Pemberdayaan Masyarakat Kelurahan Penanggungan, Dr.Wahyu Wiyani selaku Sekretaris LPPM Universitas Merdeka, Prof. Ir. H. Agus Suprapti, M.Sc.,Ph.D sebagai Ketua LPPM Universitas Merdeka juga bertindak sebagai Koordinator Program Pengembangan Posdaya di Wilayah Jawa Timur Bagian Barat dan Selatan, Ngadiono yang menjabat sebagai Ketua RT. 04. RW. 06, dan yang terakhir adalah Anggota Posdaya Pasar Minggu atas nama Puriasih.

\section{Hasil dan Pembahasan}

Posdaya RT 04/RW 06 berdiri pada tanggal 16 September 2014 yang diprakarsai oleh Pak Ngadiono yang pada waktu itu baru menjabat menjadi ketua RT 04. Posdaya sendiri diresmikan dan direalisasikan setelah mendapat pendamping dari STIKMA. Ide untuk memberdayakan warganya sudah dimiliki Pak Ngadiono jauh sebelum STIKMA datang. Pada awalnya terdapat 3 Posdaya yang ada di RT 04/RW 06, yaitu Posdaya Pasar Minggu Pagi (PMP), Posdaya Gerabah dan Posdaya Lingkungan (Penghijauan). Ketiga Posdaya tersebut dibentuk dengan harapan mampu memberdayakan setiap anggota keluarga, yaitu Ibu, Bapak, dan Anak. Posdaya Pasar Minggu Pagi (PMP) merupakan konsep pasar dengan kegiatan jual beli makanan di sepanjang jalan RT 04 yang diikuti dan diprioritaskan untuk ibu-ibu yang ada disana. Posdaya Gerabah merupakan perkumpulan pengrajin gerabah yang ada di RT 04. Kegiatan membuat gerabah ini sudah ada jauh sebelum Posdaya Gerabah di bentuk dan dilakukan turun menurun sejak dulu dari generasi ke generasi.

Posdaya atau Pos Pemberdayaan Keluarga adalah sebuah program dalam peningkatan ekonomi keluarga. Tujuan utama program ini adalah pengentasan kemiskinan dan terciptanya MDG (Millennium Development Goals). Kebijakan yang berjalan terkait Posdaya di 
Tersedia Online di http://journal.unismuh.ac.id/index.php/otoritas

Otoritas : Jurnal Ilmu Pemerintahan, 6 (2), Oktober 2016, 116

Kota Malang diawali dengan MoU (Master of Understanding) antara walikota dengan 32 Perguruan Tinggi Kota Malang. Dengan adanya persetujuan ini diharapkan perguruan tinggi juga menjadi agen yang bersama dengan masyarakat melakukan perubahan dan peningkatan ekonomi masyarakat. Pelaksanan kebijakan ini lebih banyak menekankan keaktifan perguruan tinggi dibanding pemerintah daerah sendiri.

Dalam perguruan tinggi sendiri dikenal dengan Tri Dharma yang mengharuskan para civitas akademika melakukan kegiatan pengajaran, penelitian dan pengabdian masyarakat. Posdaya menjadi momentum tersendiri untuk dapat melaksanakan kegiatan pengabdian masyarakat bagi perguruan tinggi. Dengan pengabdian masyarakat yang diwujudkan dalam kegiatan KKN (Kuliah Kerja Nyata) mahasiswa, program posdaya ini memiliki kesamaan visi dan sejalan dengan salah satu dengan tri dharma perguruan tinggi. Kebijakan Posdaya ini bersifat tidak mengikat. Perguruan tinggi dan masyarakat diberi keluasaan untuk mengatur secara mandiri kebiijakan dalam Posdaya.

Dalam perspektif ilmu pemerintahan diketahui bahwa sebuah kebijakan dapat berjalan setidaknya mempertimbangkan 3 hal yaitu anggaran, waktu dan sumber daya manusia. Dari sisi anggaran, pemerintah daerah memang belum ada alokasi pendanaan khusus untuk program ini. Sebaliknya, penganggaran ini menjadi inisiatif perguruan tinggi dan masyarakat setempat. Dari sisi waktu, pelaksanaan kegiatan Posdaya ini tidak ada batasan tertentu mengenai kapan periodisasi pelaksanaan dan selesainya kegiatan. Hal ini tergantung dengan kondisi masyarakat dan kesiapan perguruan tinggi melakukan pengabdian masyarakat. Dari sisi Sumber Daya Manusia, diketahui bahwa beberapa instansi bergerak dalam ambil bagian di program Posdaya diantaranya pemerintah seperti bagian perekonomian pemerintah kota, BKBPM dan SKPD terkait seperti dinas koperasi, perguruan tinggi, pihak pak dan kelurahan dan RT serta RW setempat. Kolaborasi semua stakeholder tersebut memiliki konstribusi dalam mengembangkan program. Namun dalam pelaksanaan tugas dan wewenang koordinasi semua pihak belum berjalan, dapat diketahui bahwa struktur organisasi dan pihak yang menangani posdaya ini memiliki pihak yang banyak dan gemuk sehingga terkadang partisipasi tidak efektif.

Saat ini dalam menjalankan Posdaya, perguruan tinggi masih terbatas komunikasinya dengan pemerintah. Begitupun dengan pemerintah yang menganggap program ini adalah program yang murni partisipasi masyarakat sehingga kontribusi pemerintah adalah sebagai fasilitator. Perguruan tinggi adalah pelaksana lapang bersama masyarakat.

Dalam perspektif komunikasi terlihat bahwa dalam upaya menginformasikan posdaya pada masyarakat diketahui bahwa terdapat peran dan inisiatif (ketua RT) yang besar, meskipun dalam prosesnya RT 04 tidak mempunyai perencanaan komunikasi khusus untuk mensosialisasikan pada warga. Selain itu posdaya RT 04 ini masih belum ada struktur kepengurusan dan bersifat tidak wajib bagi warga. Meskipun demikian,respon masyarakat terhadap posdaya ini adalah rasa optimis karena dapat mengembangan ekonomi, memunculkan tokoh penggerak serta adanya perilaku bersama yang muncul atas dasar tokoh penggerak.

Pada akhir kegiatan posdaya diketahui bahwa masih belum ada evaluasi terstruktur, meskipun terlihat bahwa tokoh penggerak selaku ketua RT 04 selalu melakukan evaluasi 2 minggu sekali dengan metode door to door. Pelaporan hasil posdaya biasanya secara informal dan lisan pada kelurahan setempat dan tidak ada pertanggung jawaban tertulis karena memang dalam program ini tidak 
Tersedia Online di http://journal.unismuh.ac.id/index.php/otoritas

Otoritas : Jurnal Ilmu Pemerintahan, 6 (2), Oktober 2016, 117

dirumuskan capaian dan tujuan program. Dalam prosesnya, keterlibatan warga hanya sebagian saja, namun dari sebagian itu terbentuk solidaritas antara warga.

Meskipun kebijakan, proses komunikasi dan indikator tujuan program posdaya belum terumuskan secara maksimal pada tataran pembuatan kebijakan, nyatakanya podaya ini mampu berjalan dengan sawadaya dan partisipasi di masyarakat RT 4.

Keaktifkan pak Ngadiono selaku koordinator Posdaya menjadi indikasi bahwa keberadaan agensi untuk menggerakkan masyarakat sangat diperlukan. Semenjak adanya Posdaya membuat solidaritas warga semakin erat. Hal itu dibuktikan dengan sikap saling bantu membantu dan sikap gotong royong dalam kehidupan bertetangga ataupun melakukan kegiatan Posdaya. Warga saling meminjami modal tetangganya yang tidak memiliki modal untuk berjualan. Disisi lain, kepercayaan juga muncul akibat hubungan yang sudah terjalin dengan baik diantara para anggota Posdaya. Hal ini sekali lagi tidak terlepas dari kontribusi agen penggerak.

Setidaknya terdapat 3 hal yang dapat dirumuskan terkait dengan dinamika masyarakat penerima program posdaya dalam kacamata sosiologi yaitu terbentuknya modal sosial, terpeliharanya modal sosial dan mulai dikembangkannya modal sosial lebih luas lagi oleh masyarakat.

Sebagaimana yang dijelaskan oleh Fukuyama (1995) terbentuknya modal sosial di tidak terlepas dari peran aktor, solidaritas masyarakat dan sepaerangkat norma/aturan. Aktor sebagai agen menggerak menstimulasi tindakan bersama warga. Tindakan bersama ini menjadi sebuah rasa kebersamaan warga. Selain itu juga terdapat norma/aturan. Norma ini lahir dari masyarakat dan disepakati sebagai aturan yang mengatur tata perilaku bersama. Dalam model pemberdayaan posdaya, masyarakat telah menciptakan aturan yang mengikat. Aturan ini juga menjadi bagian yang terintegrasi dengan perilaku masyarakat. Norma menjadi bagian dalam pembentukan sebuah modal sosial karena dapat menciptakan sebuah ikatan kelembagaan diantara anggotanya. Konfigurasi antara aktor, solidaritas dan norma yang saling mempengaruhi menjadi faktor penting dalam pembentukan modal sosial.

Aspek komunikasi, informasi dan jaringan pada akhirnya merujuk pada bentuk pemeliharaan modal sosial pada kegiatan Posdaya. Mengingat semakin berkualitasnya komunikasi dan semakin luasnya relasi akan mempengaruhi banyaknya informasi yang dimiliki oleh kelompok sosial, yang selanjutnya informasi tersebut dapat dimanfaatkan untuk mengembangkan eksistensi atau memelihara hubungan baik yang sudah terjalin atau bahkan semakin mempererat interaksi sosial antar anggota Posdaya. Dalam hal ini, posdaya RT 4 menginformasikan hal yang berkiatan dengan kegiatan pemberdayaan. Dalam pemberdayaan pasar minggu misalnya akan diinformasikan kapan waktu berjualan, apa saja yang bisa dijual serta jika kekurangan modal dapat dibantu oleh sesama anggota dan tokoh penggerak. Dalam pengembangan modal sosial, tokoh penggerak dan anggota posdaya mempunyai komitmen untuk menjadi lebih mandiri. Kemandirian ini diwujudkan dengan sifat terbuka dan mampu menjalin kerjasama lain dengan pihak lain secara lebih meluas.

Dari ketiga perspektif tadi menunjukan adanya benang merah. Pertama posdaya mampu terlaksana walau peran pemerintah tidak signifikan. Hal ini dikarenakan adanya sinergitas antara perguruan tinggi dan inisiatif masyarakat yang tinggi disertai inisiator sebagai motor penggerak. Kedua posdaya berjalan tanpa proses perencanaan yang matang. Namun sejalan dengan proses posdaya berjalan dengan sistem trial and error. 
Tersedia Online di http://journal.unismuh.ac.id/index.php/otoritas

Otoritas : Jurnal Ilmu Pemerintahan, 6 (2), Oktober 2016, 118

Adanya trial and error ini justru menyebabkan hubungan antar masyarakat menguat. Karena inisiatif lahir dari masyarakat maka ketika ada masalah, masyarakat menjadi kompak dan coba untuk mencari solusi.

Ketiga posdaya dikatakan mampu memberdayakan masyarakat karena inisiatif, solusi, implementasi dan keberlangsungan telah ditunjukan oleh masyarakat sendiri. Proses intervensi sosial yang dilakukan ke masyarakat tidak terlalu mendalam. Namun masyarakat yang awalnya tidak menyadari mereka mampu berdaya akhirnya bisa mensejahterakan dirinya secara mandiri. Hakikat inilah maka posdaya dapat dikategorikan mampu memberdayakan masyarakat.

Keempat,yaitu aktor penggerak dibutuhkan komitmen yang tinggi untuk menjaga keberlangsungan posdaya. Karena itu dibutuhkan aktor yang disegani oleh masyarakat. Aktor ini dapat dipercaya dan mampu memberikan solusi. Sehingga ketika masyarakat menemukan masalah, aktor tersebut tidak berdiam diri dan menghindar. Tetapi justru menawarkan solusi yang akhirnya berjalan proses diskusi dan kesepakatan dalam masyarakat yang menghasilkan sebuah norma bersama. Aktor ini pula yang menjadi pengawas dan menjaga kebersinambungan berjalannya program pemberdayaan yang lahir dari inisiatif masyarakat.

\section{Kesimpulan}

Posdaya RT 04 di Kelurahan Penanggungan Kecamatan Klojen telah berlangsung sejak 2014. Dengan aktor penggerak tunggal hanya berada di Ketua RT maka banyak program yang muncul juga inisiatif dari aktor penggerak yaitu pada sektor ekonomi meskipun demikian program ini dapat menumbuhkan solidaritas, kepercayaan dan keterbukaan masyarakat. Pemerintah sendiri tidak terlalu banyak dilibatkan baik perencanaan, pelaksanaan dan evaluasi dikarenakan tidak ada kewajiban Perguruan Tinggi melakukan pelaporan aktivitas ini kepada pemerintah. Posdaya adalah program pemberdayaan yang dilakukan oleh perguruan tinggi dan masyarakat secara mandiri.

Ada enam faktor yang menjadi faktor pendorong keberhasilan posdaya RT 04 Kelurahan Penanggungan Kecamatan Klojen yaitu: faktor penggerak, solidaritas sosial, terbentuknya norma dan aturan, terbentuknya jaringan sosial, terbentuknya komunikasi informal dan terbentuknya pengembangan modal sosial Ada lima faktor yang menghambat kesuksesan posdaya RT 04 Kelurahan Penanggungan Kecamatan Klojen diantaranya: kebijakan yang masih bersifat mou, SKPD yang masih memandang posdaya sebelah mata, belum adanya anggaran, banyaknya posdaya yang harus dimonitoring dan evaluasi, tidak adanya kewajiban memberikan laporan dari perguruan tinggi pendamping kepada BKBPM.

Keberhasilan posdaya RT 04 Kelurahan Penanggungan meningkatkan peluang replikasi di wilayah lain. Pelajaran yang dapat ditarik dari posdaya ini dapat ditiru oleh perguruan tinggi lain yang berniat menambah daerah yang akan didampinginya. Keberhasilan itu diantaranya berasal dari inisiatif harus berasal dari masyarakat setempat (pemimpin local) dan kejelian perguruan tinggi menangkap kebutuhan masyarakat dan tidak memaksakan diri untuk menerapkan program yang telah disusun. Agar posdaya ini dapat berkesimabungan maka dibutuhkan pengorganisasian yang lebih rapi.

\section{Ucapan Terima Kasih}

Terima kasih kami sampaikan kepada Fakultas Illmu Sosial dan Ilmu Politik Universitas Brawijaya melalui BPPM yang telah menyalurkan dana pnbp untuk penelitian ini. Tidak lupa kami sampaikan apresiasi sebesar-besarnya kepada nara- 
Tersedia Online di http://journal.unismuh.ac.id/index.php/otoritas

Otoritas : Jurnal Ilmu Pemerintahan, 6 (2), Oktober 2016, 119

sumber yang telah memberikan waktu dan informasinya terkait implementasi posdaya. Dan terakhir penghargaan setinggi-tingginya kepada tim peneliti dan asisten peneliti yang telah bekerja keras di lapangan melakukan wawancara dan observasi terhadap kegiatan posdaya.. Dan pihak-pihak yang telah membantu selama penelitian berlangsung yang tidak dapat disebutkan satu persatu.

\section{Daftar Pustaka}

Anwas, 0. M. (2012). Model PAUD Posdaya sebagai Alternatif Pelaksanaan Pendidikan Anak Usia Dini Berbasis Masyarakat. Jurnal Pendidikan dan Kebudayaan, 18 (3).

Asripah, S. (2014). Peranan Posdaya Dalam Meningkatkan Kesejahteraan Keluarga Di Masyarakat. DEMOCRATIA, 1(1).

Eko, S. (2002). Pemberdayaan Masyarakat Desa. Samarinda: Badan Diklat Provinsi Kalimantan Timur.
Fukuyama, F. (1995). Trust: The Social Virtues and The Creation of Prosperity. New York: Free Press Onyx.

Naufal, A., \& Kusumastuti, Y. I. (2016). Evaluasi Program Pos Pemberdayaan Keluarga (Posdaya) (Studi Kasus Posdaya Bina Sejahtera di Kelurahan Pasirmulya, Kecamatan Bogor Barat, Kota Bogor, Jawa Barat). Jurnal Penyuluhan, 6(2).

Sheng, Y. K. (n.d). What Is Good Governance. Bangkok, Thailand: Poverty Reduction Section UNESCAP, UN Building.

Teguh, A. S. (2004). Kemitraan dan Model Model Pemberdayaan. Yogyakarta: Gava Media. 